\title{
From Executive Appointment to the Collegium System: The Impact on Diversity in the Indian Supreme Court
}

\author{
By Aparna Chandra*, William Hubbard*, and Sital Kalantry"
}

\begin{abstract}
There has been a national debate raging in India about the system of appointments for Supreme Court and High Court judges. At the founding of the Indian Supreme Court, the executive had primary authority over judicial appointments. In 1993, the Supreme Court created a new system of appointments known as the collegium system, whereby the Chief Justice of India and senior judges of the Supreme Court make new appointments to the Supreme Court as well as the High Courts. In 2014, Parliament amended the Constitution and passed a bill to create a commission to appoint judges, but the Indian Supreme Court declared the law unconstitutional.
\end{abstract}

In this article, we ascertain whether the nature of the appointments procedure impacts the biographical and other characteristics of the judges that are eventually selected. We do this by comparing the biographical characteristics of judges appointed by the executive-appointments system (prior to 1993), on the one hand, and the judges appointed by the collegium (on or after 1993) to the Supreme Court of India.

We find that both the pre-collegium and the collegium system maintain the geographical and religious diversity of India in the candidates that are appointed. However, both have failed to account for gender diversity. In addition, the path to the Supreme Court appears to have narrowed - typically those who are appointed as judges by the collegium spend longer periods in private practice and on the bench than pre-collegium judges.

\section{A. Introduction}

There has been a national debate raging in India about the system of appointments for Supreme Court and High Court judges. At the founding of the Indian Supreme Court, the executive had primary authority over judicial appointments. In 1993, the Supreme Court created a new system of appointments known as the collegium system, whereby the Chief Justice of India and senior judges of the Supreme Court make new appointments to the Supreme Court as well as the High Courts. ${ }^{1}$ In 2014, Parliament amended the Constitution and passed a bill to change the appointments system. ${ }^{2}$ A new commission was to be created consisting of the Chief Justice of India, two senior most judges of the Supreme Court after the Chief Justice of India, the Union Minister of Law and Justice, two eminent persons (nominated by a committee consisting of the Prime Minister,

\footnotetext{
${ }^{1}$ Supreme Court Advocates-on Record Association vs Union of India, AIR1994SC268; (1993)4SCC441.

2 Indian Constitutions $99^{\text {th }}$ Amendment Act.
} 
the Leader of Opposition in the Lok Sabha, and the Chief Justice of India). At least one of these eminent persons had to be a woman or a scheduled caste, scheduled tribe, religious minority or a member of other backward castes. $^{3}$

However, in October 2015, the Supreme Court found that the new appointments procedure and the constitutional amendment passed by the Parliament were unconstitutional. ${ }^{4}$ Judicial independence was cited as a key justification by the Supreme Court in rejecting the proposed commission. Instead, the Court resurrected the collegium system. However, critics of the collegium system argue (among other things) that it is undemocratic since no rationale is given by the Court to explain what criteria it uses to accept and reject candidates.

Many authors have debated the merits of the recently proposed commission (known as the National Judicial Appointments Commission or NJAC) as compared to the collegium system. In this article, we do not take a position one way or another about the appropriate method for judicial appointments. Instead, we ask whether the nature of the appointments procedure impacts the biographical and other characteristics of the judges that are eventually selected. We do this by comparing the biographical characteristics of judges appointed by the executive-appointments system (prior to 1993), on the one hand, and the judges appointed by the collegium (on or after 1993) to the Supreme Court of India, on the other hand.

While we do not mean to suggest that the judges appointed by the NJAC would have the same characteristics as the executive-appointments system, we do think it is helpful to determine what changes in judge diversity occur when moving from a system where third parties drive judicial appointments to a system where judges self-appoint.

${ }^{3}$ Id.

4 Supreme Court Advocates-on-Record-Association and Ors. V. Union of India (UOI), (2016)5SCC1; (2016)2SCC(LS)253. 
Diversity on the bench is important for a number of reasons. First, a judiciary that is representative of the people it serves is more likely to increase public confidence that it will issue fair decisions. ${ }^{5}$ Conversely, lack of diversity in judiciaries could undermine public confidence in the judicial process. As Nelson Mandela observed during his trial in South Africa's apartheid era, "Why is it that in this courtroom I face a white magistrate, am confronted by a white prosecutor, and escorted into the dock by a white orderly? Can anyone honestly and seriously suggest that in this type of atmosphere, the scales of justice are evenly balanced?" ${ }^{6}$

Second, when judges from various life-experiences are represented in a court, particularly an appellate court where more than one judge deliberates on the same case, decisions are more likely to be better informed. Drawing from studies on juries in the United States, it has been shown that racially mixed mock juries are more likely to deliberate longer, discuss a greater number of case facts, and consider issues relating to race than all-white juries. ${ }^{7}$

In this paper, we use empirical methodologies to ascertain whether there was a change in gender diversity, regional diversity, and religious diversity. We have coded the biographical characteristics of every Supreme Court judge appointed to the Court and currently sitting on the bench. In cases where there were too many missing variables, we do not report the results.

Both the pre-collegium and the collegium system maintain the geographical and religious diversity of India in the candidates that are appointed. However, both have failed to account for gender diversity. With societal changes and an increasing number of women in the bar, the lack of equal representation of women after the collegium was instituted is harder to justify than it might have been pre-collegium. In addition, the path to the

5 Arghya Sengupta et al. (eds.), Appointment of Judges to the Supreme Court of India, Transparency, Accountability, and Independence, New Delhi 2018, pp. 101-104.

6 South African History Online, 'Black Man in a White Court' Nelson Mandela's First Court Statement 1962, http://www.sahistory.org.za/archive/black-man-white-court-nelson-mandelas-first-court-statement-1962 (last accessed on 17 October 2018).

7 Anne Sasso, Group Diversity: Mock Juries Reveal Surprising Effects of Diversity on Groups, http://www.sciencemag.org/careers/2006/05/group-diversity-mock-juries-reveal-surprising-effects-diversity-groups (last accessed on July 17, 2018). 
Supreme Court appears to have narrowed - typically those who are appointed as judges during the collegium period spend longer periods in private practice and on the bench than pre-collegium judges.

In Section 1, we describe the pre-collegium, collegium and proposed reforms to the collegium system. Section 2 is an overview of our methodology. In Section 3, we present our analysis of the differences and similarities in the biographical features of pre-collegium and collegium judicial appointees to the Supreme Court.

\section{The Appointments Procedure at the Supreme Court}

In this Section, we describe the pre-1993 appointments procedure, the changes made to the appointments procedure in 1993, the new amendments proposed in 2014 to judicial appointments, and critiques of the selfappointments procedures.

During the Constitution framing process, many different proposals were mooted for the appropriate method to appoint judges to the Supreme Court and the High Courts. The framers were concerned that the appointment process should ensure that the best candidate was appointed to this high constitutional office, while at the same time ensuring that judicial independence from the other branches of government is maintained. They discussed and discarded proposals such as the President appointing judges on his own initiative, without the aid and advice of the Council of Ministers, appointments being confirmed by one or both Houses of Parliament, setting up a panel of members from various branches of government to select judges, or giving the Chief Justice of India a veto over judicial appointments. ${ }^{8}$ Ultimately, the framework that made it through to the Constitution required the appointment of Supreme Court judges to be made by the President, acting on the aid and advice of the Council of Ministers, in "consultation" with the Chief Justice of India. The President could also consult other Supreme Court and High Court judges as per her discretion. ${ }^{9}$ The role of the judiciary in the appointments process was to provide inputs and advice to the President. The President was not bound by the advice of the Chief Justice or

8 See Constituent Assembly Debates on 24 May, 1949 Part I, https://indiankanoon.org/doc/1538555/ (last accessed on October 17, 2018) and Constituent Assembly Debates on 24 May, 1949 Part II, https://indiankanoon.org/doc/798115/ (last accessed on October 17, 2018); see also B. Shiva Rao, The Framing of India's Constitution, 1967, volume 2, pp. 587, 590. See also discussions in the Constituent Assembly on May 24, 1949.

${ }^{9}$ Article 124 , Constitution of India. 
any other judge. In practice, recommendations were initiated by the Chief Justice and sent to the Minister for Law and Justice. If the Minister agreed with the suggested name, she, with the concurrence of the Prime Minister, would so advise the President, who would make the appointment. If the Minister differed from the views of the Chief Justice, she might seek the views of other judges and consult with the Chief Justice on such views or suggest another name to the Chief Justice to secure her opinion. Ultimately however, the Minister of Law and Justice would advise the Prime Minister and with the Prime Minister's concurrence, would advise the President on whom to appoint. This was thus the Executive-led appointment system. ${ }^{10}$

As early as 1958, the Law Commission of India argued that this system of appointment did not allow for the best talent to be appointed to the Court, and that in many cases "executive influence exerted from the highest quarters" was responsible for the appointment of some judges. The Law Commission was also critical of emphasis being placed on "communal and regional considerations" in making appointments to the Supreme Court. ${ }^{11}$

In 1981, this system of appointment was challenged on the ground that it impedes judicial independence. In $S$. P Gupta v. Union of India, ${ }^{12}$ (Judges I) petitioners argued that the word "consultation" in the relevant provisions of the Constitution should be read as "concurrence," and that the judiciary should exercise a veto over judicial appointments. The challenge failed and the Court held that in the event of a disagreement between the Executive and the Chief Justice on whom to appoint as a judge of the Supreme Court, the views of the Executive would prevail.

Another challenge was mounted against this provision in 1993. Overturning its previous decision, the Court, in Supreme Court Advocates on Record Association v. Union of India, ${ }^{13}$ (Judges II) held that the "ultimate power' of appointment vested in the executive was being abused, and the existing system of appointments had resulted in merit being overlooked due to interference by the executive. ${ }^{14}$ The Court held that judicial

\footnotetext{
10 Law Commission of India, 80 th Report on the Method of Appointment of Judges 16-17 (1979).

${ }^{11}$ Law Commission of India, 14 ${ }^{\text {th }}$ Report on Judicial Administration Volume 1, page 34 (1958).

12 AIR 1982 SC 149.

13 (1993) 4 SCC 441.

${ }^{14}$ Interestingly, in the decade before the judgment, i.e., between 1983 and 1993, only 7 of 547 appointments to the Supreme Court and the various High Courts had been made without the concurrence of the Chief Justice of India.
} 
independence is part of the unamendable basic structure of the Constitution, and to protect this principle, the judiciary should have 'primacy' over the appointments process. The term "consultation" with the Chief Justice was interpreted to mean that the Chief Justice had to concur in the appointment of the judge. The opinion of the Chief Justice was in turn not her individual opinion, but that of the Chief Justice in consultation with a collegium of the two senior-most judges of the Supreme Court, and the senior-most judge of the Supreme Court from the High Court of the candidate. If the government differed in its opinion, it could send the recommendation back to the collegium. However, if the Chief Justice reiterated the decision, the government would be bound by it. This judgment introduced the collegium-led appointments system.

In an advisory opinion issued in 1998 (Judges III), the Supreme Court modified and further clarified the appointments system. ${ }^{15}$ It held that the collegium for appointment to the Supreme Court would comprise the Chief Justice and the four senior-most judges of the Court. In the 1993 and the 1998 judgments, the Court also stated that the inter-se seniority of judges within their High Court and their all India seniority should be the primary ground for appointment to the Supreme Court. However, other considerations, such as outstanding merit and ensuring regional and other diversity, would be grounds to depart from the seniority norm. ${ }^{16}$

The collegium system has come in for its fair share of criticism. Critics point to the lack of transparency in the system, especially the lack of criteria for appointments and the absence of publicly disclosed reasons for why a person was found suitable for appointment. Further, critics contend that the opaqueness and lack of reasons in the appointments process has meant that the system is rife with corruption and nepotism. ${ }^{17}$

In 2014, Parliament amended the Constitution and passed a legislation to overhaul the judicial appointment process. It set up the National Judicial Appointments Commission, comprising the Chief Justice of India, the two senior-most judges of the Supreme Court after the Chief Justice, the Union Law Minister and two eminent persons to be selected by a committee comprising of the Prime Minister, the Leader of the Opposition in the Lok

\footnotetext{
15 In re: Presidential Reference No. 1 of 1998, (1998) 7 SCC 739.

${ }^{16}$ See Judges III.

17 See a recounting of these criticisms in the opinion of Justice Kurian (concurring) and Justice Chelameshwar (dissenting) in Supreme Court Advocates on Record Association v. Union of India, 2016 (5) SCC 1.
} 
Sabha and the Chief Justice of India. At least one of the eminent persons would be a member of the Scheduled Castes/ Scheduled Tribes/ Other Backward Castes/ Religious Minorities or a woman. If two members of the Commission voted against the appointment of a person, the person would not be appointed.

This amendment and law were challenged before the Supreme Court in Supreme Court Advocates on Record Association v. Union of India (Judges IV). ${ }^{18}$ The Court, by majority struck down the amendment for violating the basic structure of the Constitution, on the ground that the new procedure brings in the possibility of political influence, which impede judicial independence. Since judicial independence is part of the unamendable basic structure of the Constitution, the amendment, and consequently the statute framed under it, fail.

Recognizing, however, the concerns with the collegium system, the Court held a "consequential hearing," and asked for suggestions from the wider public on required reforms in the collegium system. While it ultimately left the decision of finalizing the procedure for working of the collegium to the Government in consultation with the collegium (an issue that has not yet been resolved), the Court opined that reform of the collegium should focus on specifying eligibility criteria for appointments, introducing a transparent process for decision-making, setting up a permanent secretariat to assist the collegium for better management of the appointments system, and a mechanism to entertain complaints against those who are being considered for appointment, among other issues. ${ }^{19}$

Since October 2017, the Supreme Court has started uploading the resolutions of the collegium onto the Supreme Court website. These resolutions are broadly worded and give some indication of why a person is being recommended for appointment to the Supreme Court. However, they do not discuss the material on the basis of which the recommendations are made. For example, in January 2018, the collegium recommended that Justice K. M. Joseph, then the Chief Justice of the Uttarakhand High Court, be appointed to the Supreme Court. The collegium resolution noted that Justice Joseph was not the senior most Chief Justice or High Court judge (he was number 42 in the all India seniority list at that time) but deemed him to be "more deserving and suitable in all respects" than all other high court judges. ${ }^{20}$ The collegium did not explain the basis on which it had reached

182016 (5) SCC 1.

${ }^{19}$ Supreme Court Advocates on Record Association v. Union of India, December 16, 2015 order.

20 The Hindu, More Deserving and Suitable: Collegium, https://www.thehindu.com/news/national/more-deserving-andsuitable-collegium/article23688332.ece (last accessed October 17, 2018). 
this conclusion. In May, the President rejected the recommendation. The government reasoned that Justice Joseph was not the senior most high court judge, his parent High Court (Kerala) already had a judge in the Supreme Court and two high court chief justices while many other high courts had no such representation, and that there was no representation from Scheduled Caste and Scheduled Tribe communities in the Supreme Court. ${ }^{21}$ In July, the Supreme Court reiterated its recommendation stating that the government had not made any adverse comments against Justice Joseph's suitability for the post. ${ }^{22}$ Since the recommendation was reiterated unanimously, as per the decision in Judges II and Judges III, the President appointed Justice Joseph to the Supreme Court.

\section{Methodology}

For this study, we created two datasets. Our primary dataset includes biographical information on all judges appointed to the the Supreme Court of India (SCI) from its founding through March 2018. With this dataset, we can compare the diversity of judges appointed during the pre-collegium period to the diversity of judges appointed since the onset of the collegium system in October 1993.

This dataset was created by student researchers based out of Cornell Law School and National Law University, Delhi using a template created by the authors to enter biographical information gleaned from the website of the SCI into an Excel spreadsheet. The authors then converted the data to Stata format for statistical analysis, conducted checks for coding errors, and corrected ambiguities or errors in the coded data. After processing, this data formed our "Supreme Court" dataset.

Although we collected data for all judges of the SCI throughout its history, our focus is on changes (if any) in the diversity of the SCI brought about by the change to the collegium system in 1993. For this reason, our preferred version of the primary dataset includes only judges appointed since 1970 - a time period that excludes judges who spent most of their careers in the colonial legal system as judges or lawyers (and who thus may systematically differ from judges appointed during the collegium system for reasons entirely unrelated to the collegium) and which ensures that the pre-and post- subsets of the data have approximately identical durations.

\footnotetext{
21 Krishnadas Rajagopalan, Collegium Defers Decision on Govt.'s Objection to Justice K.M. Joseph's Elevation to SC, https://www.thehindu.com/news/national/sc-collegium-defers-decision-on-govts-objection-to-justice-josephselevation/article23749361.ece (last accessed October 17, 2018).

22 The Wire, SC Collegium Reiterates Elevation of Justice K.M. Joseph, https://thewire.in/law/justice-km-josephelevated-sc-collegium-reiterates (last accessed October 17, 2018).
} 
Summary statistics for this dataset appear in Tables 1 through 3. In our Appendix, we report summary statistics for the entire dataset.

Table 1 also reports the results of difference-in-means tests that compares the average characteristics of Supreme Court judges in the pre-collegium and collegium periods. Table 1 notes several statistically strong differences: judges appointed by the collegium are older, with more years of legal experience, and are overwhelmingly drawn from the ranks of high court chief justices. We discuss these differences further below.

Our secondary dataset includes biographical information on all chief justices of the high courts since 1993. As the results from our primary dataset show, nearly all judges appointed to the SCI under the collegium were chief justices of their high courts. By studying the chief justices of the high courts, therefore, we are examining the characteristics of the single group of individuals most likely to be selected by the collegium for appointment to the SCI.

This dataset was created by a team of coders, research assistants of two of the authors, who were students at Cornell Law School in the United States and National Law University, Delhi, in India. Each coder used a template created by the authors to enter biographical information gleaned from the websites of the high courts into an Excel spreadsheet. The coding teams at Cornell Law School and NLU Delhi worked independently to compile a comprehensive list of high court chief justices and enter their biographical attributes. One of the authors then compiled the spreadsheets, converted them Stata format for statistical analysis, and conducted checks for coding errors and inter-coder consistency. ${ }^{23}$ When necessary, the coders or the authors themselves identified and corrected ambiguities or errors in the coded data. After this process of compiling, reviewing, and correcting the data, the processed data formed our "High Court Chief Justices" dataset. Summary statistics for this dataset appear in Table 4.

Table 4 also reports the results of difference-in-means tests that compare the average characteristics of male high court chief justices to the averages for female high court chief justices. As Table 4 indicates, the overwhelming share of the dataset is composed of male judges-230 men and 12 women. Given the small number of women

${ }^{23}$ When one spreadsheet had a non-missing value for a variable and one contained a missing value, the authors used the non-missing value in the final dataset. Results for variables with poor intercoder reliability are not reported. 
in the sample (only 2 of whom were appointed to the SCI), we do not conduct regression analyses in addition to the difference-of-means tests. As Table 4 makes clear, for most variables, no statistically significant differences appear even when comparing means with no controls. Nonetheless, a large but not statistically significant difference in the rate at which women and men chief justices are appointed to the SCI is apparent in Table 4. We discuss this difference below.

\section{Analysis}

In this section, we review the findings of our empirical analysis. We discuss the differences in the characteristics of the Supreme Court judges pre-collegium and collegium, primarily relying on the difference-in-means tests reported in Tables 1 and 4. We supplement this analysis for those variables in which statistically significant differences exist with the results regressions that control for linear time trends. In this way, we can separate a discrete jump in the biographical characteristics of the judges that began with the institution of collegium from a long-term trend that began before (and continued after) the collegium was established. Tables reporting regression results appear in the Appendix.

First, we document a set of notable, statistically significant changes in the composition of the Court during the collegium system. Collegium judges are older and (consistent with being older) have been members of the bar prior to their appointment to the SCI. And perhaps most dramatically, the proportion of Supreme Court judges who were previously high court chief justices is also much higher-about 30 percentage points higher!

Second, we report the extent to which the diversity of the SCI has increased during the collegium period. As we discuss in more detail below, our findings suggest that gender diversity, regional diversity, and religious diversity of pre-collegium appointment judges and collegium-appointed judges remained relatively unchanged. In other words, there is no indication that the collegium system brought with it any dramatic changes in these forms of diversity. With respect to regional and religious diversity, this lack of change is unsurprising. It has long been a norm that regional and religious diversity on the SCI generally proportionately reflect the geography and religious population statistics of India.

One might have hypothesized, however, that the collegium system might have had an effect on the representation of scheduled castes or women on the Court. To the extent that opportunities in the legal profession have improved over time for previously excluded groups, one might expect that more members of scheduled castes and more women to reach the apex of the profession as Supreme Court judges. This trend toward greater representation of 
scheduled castes and women could occur regardless of the collegium system. Of course, the collegium system might accelerate this process (if the collegium actively sought to appoint women judges or members of scheduled castes) or retard this process (if the collegium judges, either intentionally or unintentionally, selected judges whose demographic characteristics matched the historical composition of the Court).

\section{Background Experience: Significant Changes}

When comparing pre-collegium and collegium period judges in Table 1, a distinct pattern emerges: Judges during the collegium era are on average older and more likely to have been chief justices of high courts. In other words, collegium judges appear to have a longer but narrower path to the Supreme Court than pre-collegium judges. Judges are older at their appointment to the SCI in the collegium period, by almost a year and a half. The average age rises from 58.5 to 59.9 , significant at the $1 \%$ level. (This pattern holds in the full data. In regressions with a control for time, the result is qualitatively similar but not statistically significant.) Also, judges have more legal experience at their appointment to the SCI in the collegium period, by about two years. The average number of years as members of the bar rises from 19.7 to 21.9 years, significant at the $1 \%$ level (This pattern holds in the full data. In regressions with a control for time, the result is qualitatively similar but not statistically significant.). These differences may in part reflect the fact that as the judiciary has grown over time, a larger pool of potential appointees means that the appointing power (regardless of whether it is the collegium or not) can select more experienced judges for elevation to the SCI.

Finally, judges are much more likely to have been the chief judge of a lower court in the collegium period, by a wide margin. The rates are $53 \%$ pre-collegium and $86 \%$ collegium, significant at the $1 \%$ level. This pattern holds in the full data and in all regressions, including those controlling for time trends. This is the strongest, most robust result among all of the variables tested. This result is to be expected after the holding in Judges II, reiterated in Judges III, that the primary criteria for appointment to the Supreme Court should be inter-se seniority amongst judges of the same High Court, and all India seniority of High Court judges.

This result is important for understanding the diversity of the SCI for at least two, related reasons. First, it suggests that although the collegium in principle has a large pool of potential appointees to choose from, it is largely limiting itself to making appointments from a very select group: high court chief justices. This is likely to reduce the diversity of the SCI to the extent that other life paths are less likely to be represented on the Court. Second, to the extent that diversity of gender, for example, is important, the diversity of high court chief justices 
takes on paramount importance. Given that the SCI itself appoints the chief justices of the high courts, it is within the power of the SCI to determine how diverse this crucial pool of potential SCI appointees is.

\section{Regional and Religious Diversity: No Noteworthy Changes}

There is no statistically significant difference in the distribution of high courts from which judges were elevated pre- and collegium period or in the distribution of parent high courts of the judges elevated to the SCI. ${ }^{24}$ See Tables 2 and 3. To the extent that one might hypothesize that, for the simple reason of geographical proximity, the collegium of the SCI would favor judges of the Delhi High Court, this hypothesis finds little support in our data. There is no statistically significant change in the share of judges elevated from the Delhi High Court in particular. Nonetheless, the increase in the share of judges elevated from the Delhi High Court is consistent with this prediction ( $3 \%$ pre versus $6 \%$ post). In any event, the judges appointed to the Court pre- and collegium period are generally reflective of the regional diversity of India. In Figure 1, we compare the percent of judges elevated from each high court to the percent of the total (current) Indian population within the jurisdiction of each high court. As these figures indicate, there is a rough correspondence between the two.

There is no large or statistically significant difference in the share of judges who are Hindu pre- and collegium period (79\% pre- collegium versus $84 \%$ collegium). This is consistent with Hindus as a share of the population of India, which is approximately $80 \%$ as of $2011 .{ }^{25}$

\section{Caste and Gender Diversity: A Noteworthy Lack of Change?}

There is no statistically significant difference in the share of judges who are members of scheduled castes precollegium and collegium, although the difference is a large decrease in percentage terms (4\% pre-collegium versus $1 \%$ collegium, corresponding to 3 and 1 justices, respectively). Given that one might expect that over time representation of scheduled castes would rise, this lack of statistically detectable change - and in fact, change in the opposite direction - suggests that the collegium system has not been accompanied by an emphasis on the elevation of judges from scheduled castes to the higher echelons of the judiciary.

Similarly, there is no statistically significant difference in the share of judges who are female in the pre-collegium and collegium periods, although the difference is a large increase in percentage terms (1\% pre-collegium versus $4 \%$ under the collegium, corresponding to 1 and 5 women justices, respectively). When using a regression

\footnotetext{
${ }^{24}$ We define "parent high court" as the first high court to which a judge was appointed.

25 See https://en.wikipedia.org/wiki/Hinduism_in_India.
} 
analysis to control for a linear time trend in the likelihood of an appointed judge being female, the collegium is associated with only a 1 percentage point increase, which is not statistically significant. (See Appendix.) We note, however, that after the end of our sample period, two female justices have been appointed to the Court. ${ }^{26}$

With the increasingly number of women in the bar and social changes recognizing women's rights, we would have expected that the collegium system to be associated with a greater number of women judges on the Supreme Court, but there appears to have been no meaningful change in the likelihood of a female appointment to the SCI following the establishment of the collegium. This is particularly troubling during the collegium period because of the significant increase of women practicing law. While we were not able to find national data straddling the pre-collegium and collegium periods, we do have regional data that suggests that the ratio of women lawyers relative to male lawyers increased dramatically from the pre-collegium to the collegium period. In Uttar Pradesh, during the period from 1962 to 1997, 3.12\% of all lawyers that registered were women. But from 1998 to 2005, $12.3 \%$ of the lawyers that registered were women. ${ }^{27}$ In Delhi, we observe a similarly large increase in the number of female practicing lawyers. During the period from 1981 to 1990 , women were only $8.1 \%$ of lawyers, but from 1991 to 2000, women constituted $22 \%$ of all lawyers. ${ }^{28}$ Despite the increase in relative number of women lawyers to male during the collegium period, the proportion of female judges relative to male judges has not increased significantly.

We note, however, that of the (mere) four female justices who were appointed by the collegium from 1993 through the end of our sample period (March 2018), three of the four were appointed in the current decade (since 2010). This suggests that the pace of appointments of women judges to the SCI may be accelerating. (It is also notable that in 2018, two female judges have been appointed to the SCI.) Nonetheless, it remains the case that

\footnotetext{
${ }^{26}$ One justice, Indu Malhotra, was appointed on 27 April 2018, shortly after the end of our sample period. Another female justice, Indira Banerjee, was appointed on 7 August 2018. See https://www.sci.gov.in/chief-justicejudges.

27 Saurabh Kumar Mishra, "Women in Indian Courts of Law: A Study of Women Legal Professionals in the District Court of Lucknow, Uttar Pradesh, India," e-Cadernos, available at https://journals.openedition.org/eces/1976 (last accessed October 30, 2018).

28 Sheetal Sharma, PHD thesis, Jawaharlal Nehru University, Chapter 4, Indian Women in the Legal Profession, p. 101 (2002), http://shodhganga.inflibnet.ac.in/bitstream/10603/29299/12/12_chapter\%204.pdf (last accessed October 18, 2018).
} 
the three women appointments in our data are less than $8 \%$ ( 3 out of 40 ) of the appointments during the period since $2000 .^{29}$

Given our particular interest in gender diversity on the Court, the highly salient and pressing issues related to women's rights before the Court, and - as a practical matter - the greater ease of coding gender information on judges, we conducted further research on gender in the high courts. To further our understanding of the lack of gender diversity on the Court, we compared the path of female and male judges to the Supreme Court during the collegium system. To do this, we utilized our secondary dataset of high court chief justices.

The collegium does not appear to preference appointments of female chief justices of high courts to the Supreme Court. First, among male chief judges in the sample, about $36 \%$ were elevated to the SCI, while only $25 \%$ of female chief judges in the sample were elevated to the SCI. This difference is not statistically significant, although it is large (with only 12 female chief judges, it is possible that the difference is due to random chance, even if the probability of any given chief judge being elevated is the same for men and women).

Although not statistically significant, this difference is (at least) somewhat concerning, given that the SCI in the collegium period appoints its members overwhelmingly from the ranks of high court chief justices, and so few women have been chief justices of high courts, even since 1993, when the collegium began. (Again, only 12 out of 242 judges in our high court chief justice dataset are women - that is less than 5 percent of the total!) Thus, even if every single woman in our chief justice data were elevated to the SCI, women would comprise barely 10 percent of the total number of Supreme Court judges in the collegium period (there have 12 women high court chief justices and 118 Supreme Court judges in the collegium period). If the collegium is committed to appointing primarily high court chief justices to the SCI, then women high court chief justices would need to be appointed at a very high rate to make a dent in the lack of gender diversity on the Supreme Court of India. Instead, what we observe is that women high court chief justices are being appointed at a low rate, relative to men.

29 This share increases to $11 \%$ if we include the four justices (including two women justices) appointed since the end of our sample period. 
Further, the lower rate of appointment of women high court chief justices to the SCI cannot be easily attributed to women chief justices having less experience or seniority than the male counterparts. Among those chief judges elevated to the SCI, tenure in the lower courts is nearly the same for men and women (14.0 years and 14.7 years, respectively). Male and female chief judges are appointed at basically the same age (58.9 years for men and 59.6 years for women). Among those who were later elevated to the SCI, the age at appointment to chief judge is slightly higher for women (59.3 versus 57.9 for men), but again the difference is not statistically significant. Male and female chief judges have nearly the same experience as members of the bar pre-appointment (22.8 years for men and 21.8 years for women).

And in any event, lack of seniority as a chief justice does not in itself seem to be an impediment to the elevation of women to the SCI. Among those chief judges elevated to the SCI, women were actually elevated earlier their tenures as chief justices relative to men (1.12 years tenure as chief justice for women versus 1.98 for men, but the difference is not statistically significant). Thus, on the whole women chief justices do not appear to be less (or more) experienced than their male counterparts.

There is an indication in our data that, if anything, women CJs have to be more qualified than men to be appointed to the SCI. In our data women chief judges are statistically significantly more likely than men to have been appointed chief judge in another high court (19\% of male chief judges and 50\% of female chief justices, statistically significant at the $1 \%$ level). Women chief justices, in other words, on average have experience across more high courts during their careers as chief justices. Because our coding of high court data in the high court chief justices dataset was less consistent across coders than the coding of other variables in our data, we do not want to over-emphasize this result, but we see this result as suggestive that, even among the most favored group for appointment to the SCI- high court chief justices - women appear to have a tougher path to the Supreme Court.

If the Supreme Court continues to prioritize high court judges for appointment to the Supreme Court, therefore, it appears that, to increase the gender diversity of the Supreme Court, the collegium must both appoint more female judges to high courts to increase its pool of candidates - only 12 high court chief justices in the collegium period have been women (less than $5 \%$ of the total) - and elevate more women chief justices to the Supreme Court (only $25 \%$ have been elevated, as opposed to $36 \%$ of men chief justices). 


\section{B. Conclusion}

Our findings suggest that while the collegium is focused on certain forms of diversity, it is not focused on other forms of diversity. It also suggests that the path to the SCI in the collegium period is more rigid than it was precollegium. Today's judicial candidates are more likely to have spent a longer time in private practice, as a sitting judge, and more likely to be a chief justice of a high court before their appointment to the Supreme Court.

This article informs the debates about merits of collegium system. The pre-collegium system is different from the NJAC or another similar system that might be adopted in place of the collegium system so the comparison between the pre-collegium system and the collegium system has its limitations. However, the results do suggest that the collegium has not done a lot to make the court more gender balanced. Advancing gender diversity might require outside influence.

Figure 1. Percent of Supreme Court Judges Elevated from Each High Court and Percent of Indian Population within Each High Court

01.png

Source. Population data from 2011 Official Indian Census; judge and population percentages from author's calculations.

\section{pagebreak}

Table 1. Summary Stats, Judges Since 1970 


\begin{tabular}{|c|c|c|c|}
\hline Variable klein & $\begin{array}{l}\text { Mean } \\
\text { Pre-Collegium } \\
\text { Period }(\mathrm{N})\end{array}$ & $\begin{array}{l}\text { Mean Collegium } \\
\text { Period }(\mathrm{N})\end{array}$ & $\begin{array}{l}\text { Diff in Means } \\
\text { Significance }\end{array}$ \\
\hline $\begin{array}{l}\text { Age at Appointment to SCI } \\
\text { (years) }\end{array}$ & $58.5(70)$ & $59.9(118)$ & $* *$ \\
\hline $\begin{array}{l}\text { Age at Appointment to CJI } \\
\text { (years) }\end{array}$ & $62.8(16)$ & $63.5(15)$ & \\
\hline Years in Bar Pre-Appointment & $19.7(69)$ & $21.9(118)$ & $* *$ \\
\hline Tenure as CJI (years) & $1.58(16)$ & $1.09(15)$ & \\
\hline Tenure in Lower Court (years) & $14.7(68)$ & $14.3(114)$ & \\
\hline Hindu Religion & $.79(68)$ & $.84(113)$ & \\
\hline Female & $.01(70)$ & $.04(118)$ & \\
\hline Scheduled Caste & $.04(70)$ & $.01(118)$ & \\
\hline Foreign Degree & $.15(68)$ & $.09(118)$ & \\
\hline Elevated from Lower Court & $.97(70)$ & $.97(118)$ & \\
\hline Was CJ of Lower Court & $.53(70)$ & $.86(118)$ & $* *$ \\
\hline Had Done Private Practice & $.43(54)$ & $.36(110)$ & \\
\hline Had Been Gov't Advocate & $.58(52)$ & $.64(111)$ & \\
\hline
\end{tabular}


Judge of Court Below High $.17(66)$

$.08(116)$

$+$

Courts

Note. ${ }^{* *},{ }^{*}$, and + denote statistical significance in a two-tailed t-test at the $1 \%, 5 \%$, and $10 \%$ levels, respectively. Horizontal line separates continuous variables from indicator variables.

Table 2. High Court Elevated From (Judges Since 1970) 


\begin{tabular}{|c|c|c|c|}
\hline Variable klein & $\begin{array}{l}\text { Number Pre-Collegium } \\
\text { Period (\%) }\end{array}$ & $\begin{array}{l}\text { Number Collegium Period } \\
(\%)\end{array}$ & Total \\
\hline Allahabad & $7(10.3)$ & $6(5.3)$ & $13(7.1)$ \\
\hline Andhra Pradesh & $4(5.9)$ & $9(7.9)$ & $13(7.1)$ \\
\hline Bombay & $5(7.4)$ & $10(8.8)$ & $15(8.2)$ \\
\hline Calcutta & $8(11.8)$ & $8(7.0)$ & $16(8.8)$ \\
\hline Chhattisgarh & $0(0.0)$ & $1(0.9)$ & $1(0.6)$ \\
\hline Delhi & $2(2.9)$ & $7(6.1)$ & $9(5.0)$ \\
\hline Gauhati & $3(4.4)$ & $4(3.5)$ & $7(3.9)$ \\
\hline Gujarat & $3(4.4)$ & $3(2.6)$ & $6(3.3)$ \\
\hline Himachal Pradesh & $2(2.9)$ & $3(2.6)$ & $5(2.8)$ \\
\hline Jammu & $3(4.4)$ & $4(3.5)$ & $7(3.9)$ \\
\hline \multicolumn{4}{|l|}{ Kashmir } \\
\hline Jharkhand & $0(0.0)$ & $3(2.6)$ & $3(1.7)$ \\
\hline Karnataka & $5(7.4)$ & $8(7.0)$ & $13(7.1)$ \\
\hline Kerala & $5(7.4)$ & $8(7.0)$ & $13(7.1)$ \\
\hline Madhya Pradesh & $3(4.4)$ & $5(4.4)$ & $9(4.4)$ \\
\hline Madras & $6(8.8)$ & $7(6.1)$ & $13(7.1)$ \\
\hline
\end{tabular}




\begin{tabular}{llll}
\hline Variable klein & $\begin{array}{l}\text { Number Pre-Collegium } \\
\text { Period }(\%)\end{array}$ & $\begin{array}{l}\text { Number Collegium Period } \\
(\%)\end{array}$ & Total \\
\hline Meghalaya & $0(0.0)$ & $1(0.9)$ & $1(0.6)$ \\
\hline Orissa & $2(2.9)$ & $10(8.8)$ & $8(4.4)$ \\
\hline Patna & $3(4.4)$ & $5(4.4)$ & $9(5.0)$ \\
\hline Punjab & $3(4.4)$ & $6(5.3)$ & $9(5.0)$ \\
Haryana & & & $1(0.6)$ \\
\hline Rajasthan & $4(5.9)$ & $5(4.4)$ & $182(100)$ \\
\hline Uttarakhand & $0(0.0)$ & $114(100)$ & \\
\hline Total & $68(100)$ & & \\
\hline
\end{tabular}

Note. Pearson's X'(21)=12.53, $p=0.924$, Fisher's exact test $p=0.961$.

Table 3. Summary Stats, Parent High Court (Judges Since 1970) 


\begin{tabular}{|c|c|c|c|c|}
\hline Variable klein & $\begin{array}{l}\text { Number } \\
\text { Period (\%) }\end{array}$ & Pre-Collegium & Number Collegium Period (\%) & Total \\
\hline Allahabad & $7(10.9)$ & & $10(9.0)$ & $17(9.7)$ \\
\hline Andhra Pradesh & $0(0.0)$ & & $5(4.5)$ & $5(2.9)$ \\
\hline Bombay & $5(7.8)$ & & $10(9.0)$ & $15(8.6)$ \\
\hline Calcutta & $7(10.9)$ & & $8(7.2)$ & $15(8.6)$ \\
\hline Delhi & $2(3.1)$ & & $10(9.0)$ & $12(6.9)$ \\
\hline Gauhati & $3(4.7)$ & & $6(5.4)$ & $9(5.1)$ \\
\hline Gujarat & $4(6.3)$ & & $7(6.3)$ & $11(6.3)$ \\
\hline Himachal Pradesh & $0(0.0)$ & & $2(1.8)$ & $2(1.1)$ \\
\hline Jammu and & $3(4.7)$ & & $2(1.8)$ & $5(2.9)$ \\
\hline Kashmir & & & & \\
\hline Karnataka & $4(6.3)$ & & $7(6.3)$ & $11(6.3)$ \\
\hline Kerala & $6(9.4)$ & & $7(6.3)$ & $13(7.4)$ \\
\hline Madhya Pradesh & $3(4.7)$ & & $6(5.4)$ & $9(5.1)$ \\
\hline Madras & $7(10.9)$ & & $8(7.2)$ & $15(8.6)$ \\
\hline Orissa & $2(3.1)$ & & $5(4.5)$ & $7(4.0)$ \\
\hline Patna & $3(4.7)$ & & $10(9.0)$ & $13(7.4)$ \\
\hline
\end{tabular}




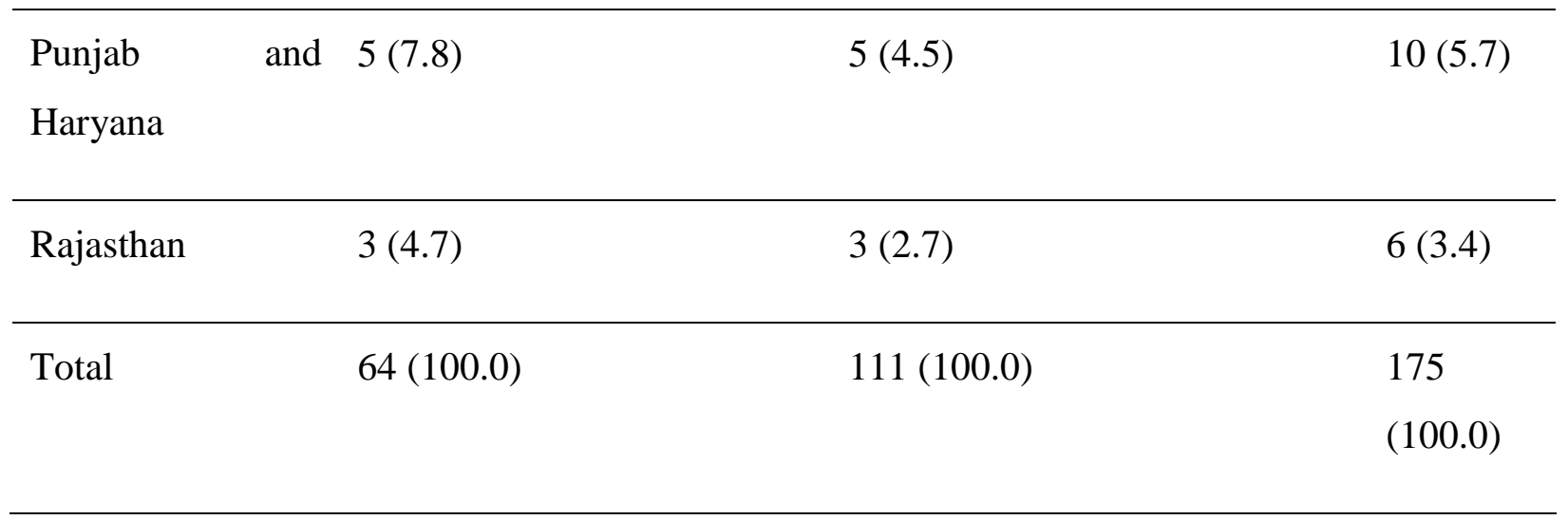

Note. Pearson's $X^{2}(16)=11.86, p=0.753$, Fisher's exact test $p=0.791$.

pagebreak

Table 4. Summary Statistics, High Court Chief Justices Data 


\begin{tabular}{|c|c|c|c|}
\hline Variable klein & $\begin{array}{l}\text { Mean } \\
\text { Males (N) }\end{array}$ & $\begin{array}{l}\text { Mean } \\
\text { Females (N) }\end{array}$ & $\begin{array}{l}\text { Diff in Means } \\
\text { Significance }\end{array}$ \\
\hline Elevated to SCI (indicator) & $0.36(230)$ & $0.25(12)$ & \\
\hline Age at Appointment to SCI (years) & $60.1(91)$ & $60.1(3)$ & \\
\hline $\begin{array}{l}\text { Tenure as CJ among those elevated to } \\
\text { SCI (years) }\end{array}$ & $1.98(92)$ & $1.12(3)$ & \\
\hline $\begin{array}{l}\text { Tenure in Lower Court Prior to SCI } \\
\text { Appointment (years) }\end{array}$ & $14.0(86)$ & $14.7(3)$ & \\
\hline Age at Appointment as $\mathrm{CJ}$ (years) & $58.9(186)$ & $59.6(11)$ & \\
\hline -- among those later elevated to SCI & $57.9(79)$ & $\begin{array}{l}59 .(3) \\
3(2)\end{array}$ & \\
\hline -- among those not later elevated & $59.6(107)$ & $59.7(9)$ & \\
\hline Appointed CJ of more than $1 \mathrm{HC}$ & $0.19(230)$ & $.50(12)$ & $* *$ \\
\hline Years in Bar Pre-Appointment & $22.8(169)$ & $21.8(10)$ & \\
\hline
\end{tabular}

Note. ${ }^{* *},{ }^{*}$, and + denote statistical significance in a two-tailed t-test at the $1 \%, 5 \%$, and $10 \%$ levels, respectively. Horizontal line separates continuous variables from indicator variables. 